\title{
A NEW SPECIES OF ARTOCARPUS (MORACEAE) FROM THAILAND
}

\author{
C.C. BERG \\ Bergen Museum, University of Bergen, Allégate 41, 5007 Bergen, Norway; \\ Nationaal Herbarium Nederland, Universiteit Leiden branch, \\ P. O. Box 9514, 2300 RA Leiden, The Netherlands
}

\section{SUMMARY}

A new species, Artocarpus thailandicus, is described from Thailand.

Key words: Moraceae, Artocarpus, Thailand.

\section{INTRODUCTION}

The majority of the Artocarpus species of the Sino-Himalayan region consist of a set of about ten closely related species with small ranges of distribution (of subg. Pseudojaca Trécul) showing more or less clear affinities to Artocarpus glaucus. Four of these species, A. hypargyreus Hance, A. petelotii Gagnep., A. styracifolius Pierre, and A. tonkinensis Gagnep. have been treated by Jarrett $(1959,1960)$ in her monograph of the genus. Four other species were described for China (Wu \& Chang, 1989). Two undescribed species were discovered during the preparation of a treatment for the Flora of Thailand, one from Vietnam with only one collection and, therefore, not ready for publication, and the other from Thailand of which several collections have been made.

\section{Artocarpus thailandicus C.C. Berg, spec. nov. - Fig. 1}

Artocarpo glauco in ramulis foliosis petiolis dense puberulis, laminae apice breviter acuminato ad apiculato ad acuto ad rotudato, venis lateralibus paucis ad paucioribus differt. - Typus: Maxwell 90-232 (holo L; iso CMU), Thailand, Chiang Mai, Chiang Dao, Doi Chiang Dao, above Sop Huay Pa Sahng-Huay Na Lao Forest Station, 725 m, 24 Feb. 1990 (m).

Tree up to $10 \mathrm{~m}$ tall, deciduous. Leafy twigs $1.5-4 \mathrm{~mm}$ thick, densely brown to yellowish puberulous, smooth, drying brown to blackish. Leaves distichous; lamina (sub) coriaceous, entire elliptic to obovate $2-13(-17)$ by $1-8.5(-10.5) \mathrm{cm}$, base rounded to cuneate, inequilateral, margin denticulate towards the apex to entire, apex short-acuminate to apiculate to acute or to rounded, upper surface sparsely brownish puberulous, more densely on the main veins, glabrescent, smooth or scabridulous, lower surface densely minutely brownish to whitish puberulous to tomentose in the areoles or also on the reticulum, more sparsely puberulous to tomentose to subhirtellous on the main veins, smooth to scabridulous, lateral veins 7-9 pairs, some furcate far from the margin, 


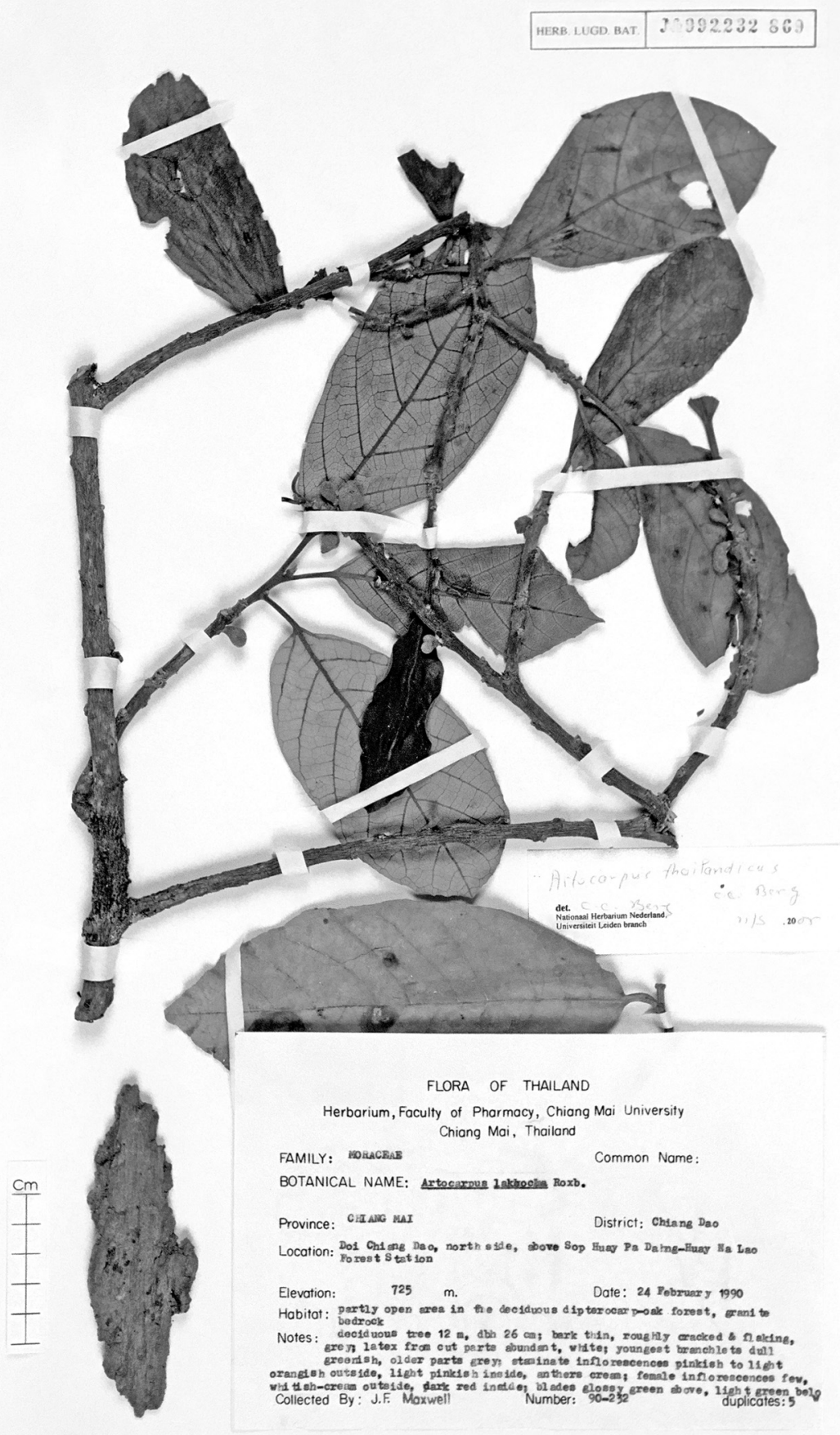

Fig. 1. Artocarpus thailandicus C.C. Berg. Leafy twigs with staminate inflorescences (Maxwell 90-232, L). 
tertiary venation scalariform, slightly prominent to flat; petiole $(0.5-) 1-2(-3.5) \mathrm{cm}$ long, 1-2 mm thick, densely brown(ish) to whitish puberulous, epidermis persistent; stipules lateral, $0.3-0.6 \mathrm{~cm}$ long, brown(ish) puberulous, caducous. Staminate inflorescences axillary and below the leaves (down to previous season's growth), solitary or in pairs, (sessile or) with a peduncle $0.1-0.3 \mathrm{~cm}$ long, minutely brownish puberulous; head cylindrical to clavate to obovoid or to pulvinate, $0.5-1.5(-1.8) \mathrm{cm}$ long, $0.2-0.8$ $\mathrm{cm}$ diam.; perianth 2- or 3-parted, c. $0.5 \mathrm{~mm}$ long; stamen c. $0.8 \mathrm{~mm}$ long, anther c. $0.2 \mathrm{~mm}$ long; interfloral bracts (sub) peltate, apical part c. $0.3 \mathrm{~mm}$ diam., densely puberulous. Pistillate inflorescences axillary, solitary; peduncle $0.2-0.7 \mathrm{~cm}$ long, densely brownish to whitish puberulous, broadening into a disc with or without basally attached bracts on its margin; head obovoid to subglobose?, stigma simple; interfloral bracts peltate, caducous, the apical part $0.2-0.3 \mathrm{~mm}$ diam., puberulous. Infructescences to $4 \mathrm{~cm}$ diam., brown velutinous; mature seeds not seen.

Distribution - Thailand, endemic.

Habitat - Deciduous (dipterocarp and oak) forest, at altitudes up to $850 \mathrm{~m}$.

Note - This species belongs to a group of species with minute indumentum in the areoles of the lamina beneath and comprising Artocarpus glaucus Blume and, e.g., A. hypargyreus and A. styracifolius. The short peduncles are shared with A. glaucus (ranging from the Malay Peninsula to N Australia) from which this species differs in the short-acuminate to rounded apex of the lamina, the smaller number of lateral veins (7-9 vs 8-15 pairs), the dense indumentum on leafy twigs and petioles, and deciduousness of the tree.

Additional specimens:

B. Hansen et al. 11071 (C, L), Phitsanulok, Thung Salaeng, 9 Feb. 1964 (st); Maxwell 90-384 (L), Chiang Mai, Mae Rim, Soi Sutep-Pui National Park, 850 m, 3 April 1990 (f); Samang \& Brant E54 (AAU), Sri Than KKU, Khao Kaen, Muang, 7 Jan. 1977 (m); T. Smitinand 10357 (AAU, C, K, L), Khon Kaen, Tha Phra, 200 m, 20 April 1967 (f); Th. Sørensen et al. 6010 (C), Chiang Mai, 1050 m, 1 Nov. 1958 (st); Th. Wongprasert 48 (K), Chiang Mai, Mae Sanarm, Hod, 800 m, 6 March $1982(\mathrm{~m})$.

\section{REFERENCES}

Jarrett, F.M. 1959. Studies in Artocarpus and allied genera, III. A revision of Artocarpus subgenus Artocarpus. J. Arnold Arbor. 50: 113-368.

Jarrett, F.M. 1960. Studies in Artocarpus and allied genera, IV. A revision of Artocarpus subgenus Pseudojaca. J. Arnold Arbor. 51: 73-140.

Wu, C.Y. \& S.S. Chang. 1989. Taxa nova nonnulla moracearum sinensium. Acta Bot. Yunnan. 11: $24-34$. 